\title{
Ulus ve Cumhuriyet Gazetelerine Göre Hatay Sorunu ve Hatay'ın Anavatana Bağlanması
}

Esin Tüylü Turan*

\section{Özet}

Türkiye Cumhuriyeti'nin Lozan Antlaşması ile çözümlenemeyen meselelerinden biri Sancak (Hatay) Sorunu'dur. İskenderun Sancağı, Mondros Mütarekesi'nin ardından Fransa'nın manda yönetimi altına girmiş, Fransa'nın Suriye'ye bağımsızlık verdiği 1930 yılında ise Sancak'a Suriye egemen olmuştur. Sancak Sorunu'nu kendi şahsi meselesi olarak addeden Mustafa Kemal Atatürk'ün önderliğinde Türkiye Cumhuriyeti, Sancak'ın önce bağımsızlığına kavuşması ve sonra da anavatana bağlanması için yoğun bir diplomasi trafiği içerisine girmiştir. Bu süreçte yaşanan gelişmeler, dönemin önemli gazeteleri olan Cumhuriyet ve Ulus gazetelerinde yoğun bir şekilde işlenmiştir. Bu makale ile Cumhuriyet ve Ulus'ta yer alan haberler ve yorumlar çerçevesinde, Sancak Sorunu'nun başlangıcından, Hatay'ın anavatana bağlanmasına kadar geçen süreç incelenecektir.

Anahtar Kelimeler: Fransa, Türkiye Cumhuriyeti, Suriye, Hatay, Antakya, İskenderun, Sancak Sorunu, Ulus Gazetesi, Cumhuriyet Gazetesi

\section{Hatay Question and the Attachment of Hatay to the Fatherland According to Ulus and Cumhuriyet Newspapers}

\section{Abstract}

One of the most important problems of the new Turkish Republic that couldn't be solved by the Lausanne Treaty is the Sanjak (Hatay) Problem. The Sanjak of Alexandretta entered under the domination of French mandate after the Armistice of Mudros and after France gave its independence to Syria, it became a part of Syria. Under the leadership of Mustafa Kemal Atatürk who considered the Sanjak problem his own problem, Turkish Republic started an intensive diplomatic traffic in order to gain the Sanjak's independency and after that the attachment of the Sanjak to the fatherland. In this process,

Doktora Öğrencisi, Sakarya Üniversitesi, Sosyal Bilimler Enstitüsü, Tarih Anabilim Dalı, Sakarya, esinatik@gmail.com. (Makale gönderim tarihi: 13.01.2017, makale kabul tarihi: 29.03.2017)

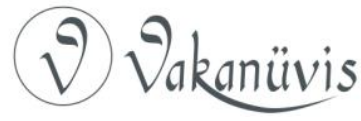


important newspapers of that period Ulus and Cumhuriyet, intensively handled the progress of this issue. With this article, this process from the beginning of the Sanjak problem to the attachment of Hatay to the fatherland will be examined in the frame of the news and comments of these two newspapers.

Keywords: France, Turkish Republic, Syria, Hatay, Antakya, Alexandretta, Sanjak Problem, Ulus Newspaper, Cumhuriyet Newspaper

\section{San Remo'dan Milletler Cemiyeti'ne Kadar Hatay Sorunu}

İskenderun Sancağı, bir toprak parçası olmasının ötesinde, Anadolu'yu Suriye'ye bağlayan ve Akdeniz ile çöl arasında liman bağlantısını sağlayan bir merkez konumundadır ${ }^{1}$. Mondros Mütarekesi'nin imzalanmasının ve Osmanlı Devleti'nin mağlup devletler arasında yer almasının ardından, Amerika Birleşik Devletleri Başkanı Wilson, müttefik devletlerin kendi aralarında imzalamış oldukları ve Rusya tarafından deşifre edilen antlaşmaları tanımayacağını ilan etti. Bunun üzerine, İngiltere ve Fransa farklı bir politika izlemeye başlayarak, manda yönetimleri kurmaya karar verdiler $^{2}$. 18-26 Nisan 1920 tarihleri arasında gerçekleşen San Remo Konferansı'nda alınan kararlar gereğince, Ingiltere ve Fransa Ortadoğu'daki bölgeleri paylaşarak manda yönetimleri kurmaya başladılar ${ }^{3}$. İki ülke arasındaki anlaşmaya göre, İskenderun Sancağı'nı da içerisine alan Suriye bölgesi, Fransa'nın himayesine bırakılmıştı.

Mondros Mütarekesi imzalandığı sırada, İskenderun Sancağı, Osmanlı Devleti'ne bağlıydı ve henüz işgal edilmemişti. Hatta savaş bittiği sırada, düşman ordusu, Halep ile Kilis arasında ve bugünkü Hatay sınırından 30-40 km uzaklıkta bulunan Katma mevkiindeydi. Misak-ı Millî’de mütareke imzalandığı tarihteki Osmanlı Devleti sınırlarının bir

\footnotetext{
${ }^{1}$ Hamit Pehlivanlı, Yusuf Sarınay, Hüsamettin Yıldırım, Türk Dış Politikasında Hatay, Ankara, 2001, s. 31.

2 Serhan Ada, Türk-Fransız İlişkilerinde Hatay Sorunu (1918-1939), İstanbul Bilgi Üniversitesi Yayınları, İstanbul, 2005, s. 71-72.

${ }^{3}$ Fahir Armaoğlu, 20. Yüzyıl Siyasi Tarihi, Ankara, 1983, s. 197.
}

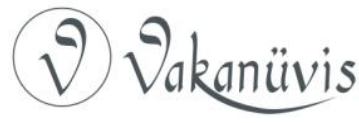


bütün olduğu ve parçalanamayacağı vurgulanmaktaydı ${ }^{4}$. İskenderun Sancağı da mütareke imzalandığında bir Osmanlı toprağıydı ve Misak-ı Millî sınırları içerisinde yer alıyordu. Bu nedenle de başka bir milletin egemenliğine bırakılması düşünülemezdi.

Bununla birlikte, 20 Ekim 1921 tarihinde Türkiye ile Fransa arasında yapılan Ankara İtilafnamesi ile İskenderun Sancağı, Suriye sınırları içerisinde bırakılmış, ancak bölgeye özel bir statü verilmiştir. Buna göre, halkının çoğunluğu Türk olan sancakta, Türk parası geçerli olacak ve halkın millî kültürünün korunması için her türlü kolaylık sağlanacaktı. Ayrıca bu antlaşma, İskenderun Sancağı'na Türkiye ve Fransa'nın garantörlüğünde ayrı bir varlık hakkı tanımaktaydı ${ }^{5}$. Bu antlaşma ile her ne kadar Sancak'ta yaşayan Türklerin hakları savunulmuş olsa da yine de Sancak, Suriye'deki Fransız manda yönetiminin egemenliğine girmiş oluyordu.

Fransa, 1926 yılının Mayıs ayında Lübnan'da, 1930 yılının Mayıs ayında da Suriye'de cumhuriyet rejimi ilan ederek, sözde bağımsızlıklarını verdi ${ }^{6}$. 1930'lu yıllarda, Türkiye, Lozan'dan arta kalan problemler de dâhil olmak üzere sorunlarının büyük çoğunluğunu çözüme kavuşturmuştu. 1936 yılına gelindiğinde Montrö Boğazlar Sözleşmesi imzalanarak, Lozan Antlaşması'ndan geriye kalan sorunlardan biri olan Boğazlar Meselesi çözüme kavuşturuldu. Atatürk, Fransa'nın Suriye'ye bağımsızlık vermeye hazırlandığı süreçte, Türkiye

\footnotetext{
${ }^{4}$ Abdurrahman Melek, Hatay Nasıl Kurtuldu, Ankara, 1966, s. 2; Figen Atabey, "Hatay'ın Anavatana Katılma Süreci", Avrasya Uluslararası Araştırmalar Dergisi, 4/7 (Temmuz 2015), s. 193.

5 S. Esin Dayı, "Hatay Devleti ve Hatay'ın Anavatana Katılması", A. Ü. Türkiyat Araştırmaları Enstitüsü Dergisi, 19 (2002), s. 332; Tarık Saygı, "Lozan Antlaşması'nda Musul Sorunu ve Hatay Meselesi", Yalova Sosyal Bilimler Dergisi, 5/10 (2015), s. 167; İsmail Soysal, "Türk-Fransız İlişkileri", Türkiye Diyanet Vakfı İslam Ansiklopedisi, c. 13, İstanbul, 1996, s. 184; Ercan Karakoç, "Atatürk'ün Hatay Davası", Bilig, 50 (Yaz 2009), s. 101; Armaoğlu, a.g.e., s. 198; Mehmet Tekin, Hatay Tarihi, Osmanlı Dönemi, Atatürk Kültür Merkezi Yayınları, Ankara, 2000, s. 219; Hatay'ın Kurtuluş Mücadelesinde Türk Ordusu, Yay. Haz: 39. Mekanize Piyade Tugay Komutanlığı Tarih Araştırma Grubu, ed. Mustafa Filiz, İskenderun, 2010, s. 132-135.

${ }^{6}$ Ada, a.g.e., s. 104; Armaoğlu, a.g.e., s. 198.
}

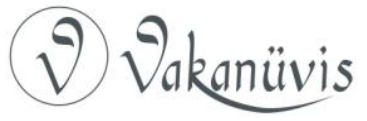


Cumhuriyeti'nin diğer bir meselesi olan Sancak Sorunu'nu Türkiye lehine çözmeye karar verdi ${ }^{7}$.

\section{Suriye'nin Bağımsızlığını Kazanması ve Sancak'ın Durumu}

Fransa,Ortadoğu'da himayesinde bulunan bölgelerde 1930 yılı başlarından itibaren ılımlı bir politika izlemeye başlamasına rağmen, Arap milliyetçilerinin direniş ve isyanları artarak devam etmekteydi. Fransa, direniş̧̧ilere karşı askerî önlemler alsa da bu durum Fransız ekonomisine ve siyasetine ağır yükler getirmekteydi. 1936 yılında İtalya'nın Habeşistan'ı ele geçirmesi ve aynı dönemde Hitler Almanya'sının Versay’ın hükümlerini tanımadığını ilanı üzerine, Fransa, Avrupa'da tehlike hissetmeye başladı. Bunun üzerine de Ortadoğu'daki sorunlarını azaltmak isteyerek, 9 Eylül 1936 tarihinde Suriye ile bir dostluk ve ittifak antlaşması imzaladı. Antlaşmanın 22 Aralık'ta imzalanmasıyla, Suriye bağımsızığına kavuştu ${ }^{8}$. Suriye'nin imzalanan bu antlaşma ile bağımsızlığına kavuşmasının ardından, Sancak'ın yönetimi de Suriye'ye geçmiştir.

Suriye'nin bağımsızlığını kazanması Türk basınında da yer buldu. Konu ile ilgili ilk açıklama, Dışişleri Bakanı Tevfik Rüştü Aras'tan geldi. Aras, 12 Eylül 1936 tarihinde Ulus gazetesinde yayınlanan demecinde, Türkiye'nin tarihi ve hissî bağlarının bulunduğu Suriye ile dostane ilişkilerini sürdürdüğü Fransa devletleri arasındaki anlaşmada, hemen hepsi Türk olan 280.000 nüfusluk İskenderun ve Antakya bölgesinde mahalli ve müstakil bir idare oluşturulacağını ümit ettiğini belirtti ${ }^{9}$. Suriye'nin bağımsızlığının ardından, Türk kamuoyunun Sancak'la ilgili beklentilerinin ifade edildiği bu ilk haberde, Sancak'ın Türkiye'ye geri verilmesinden ziyade orada yaşayan Türk halklarının korunması için bir muhtariyet yönetimi kurulmasının ümit edildiği ifade edilmekteydi.

Suriye'nin bağımsızlığını kazanmasıyla ilgili Cumhuriyet Gazetesi'nde 13 Eylül 1936 'da yayınlanan haberde, Paris'te 7-8 aydır sürmekte olan

\footnotetext{
${ }^{7}$ Karakoç, a.g.m., s. 103; Atabey, a.g.m., s. 194; Pehlivanlı, a.g.e., s. 46; Saygı, a.g.m., s. 169.

${ }^{8}$ Ayşe Aydın, "Hatay Meselesinin Çözümü Esnasında Başbakan Celal Bayar'ın Faaliyetleri", Afyon Kocatepe Üniversitesi Sosyal Bilimler Dergisi, 14/1 (Haziran 2012), s. 144; Pehlivanlı, a.g.e., s. 48; Ada, a.g.e., 104-109.

${ }^{9}$ Ulus, 12 Eylül 1936.
}

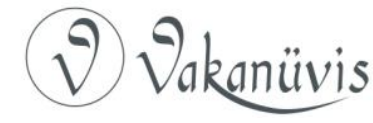


müzakereler sonucunda Suriye'nin bağımsızlığına kavuşmasından mutlak surette memnun olunduğu ve Türklerin yüzyıllardır birlikte yaşadığı Suriye halkının kendi mukadderatlarını kendi ellerine almasının mutluluk verici olduğu belirtilmekteydi. Haberde, henüz Suriye'ye bağımsızlığını kazandıran antlaşma ile ilgili kesin bir bilgiye sahip olunmamasına rağmen, halkının çoğunluğu Türk olan İskenderun ve havalisinin muhtariyet kazanmış olması gerektiği ifade edilmiştir. Nitekim Türk hükümeti, müzakereler sırasında, Fransız hükümetine bu talebini iletmişti ${ }^{10}$. Suriye'nin bağımsızlığı haberi, bir taraftan memnuniyetle karşılanırken, diğer taraftan da milli hassasiyetleri uyandırıyordu.

Mustafa Kemal Atatürk, Sancak Sorunu'nu yakından takip ediyordu. 1 Kasım 1936'da TBMM'nin açılış konuşmasında Sancak'la ilgili olarak şunları söylemekteydi:

"Bu sırada milletimizi gece gündüz meşgul eden başlıca büyük mesele, hakiki sahibi öz Türk olan iskenderun ve Antakya havalisinin mukadderatıdır. Bunun üzerinde ciddiyet ve katiyetle durmaya mecburuz. Daima kendisi ile dostluğa çok önem verdiğimiz Fransa ile aramızda tek ve büyük mesele budur. Bu işin hakikatini bilenler ve hakkı sevenler, alakamızın şiddetini ve samimiyetini iyi anlarlar ve tabi görürler ${ }^{11}$."

Atatürk, bu konuşmasıyla, Sancak Sorunu'nun üzerine düşeceğinin sinyallerini veriyordu. Ertesi gün, Sancak Sorunu'nu doğrudan ele aldığını göstermek için, İskenderun-Antakya Müdafaa-i Hukuk Cemiyeti'nin adını Hatay Egemenlik Cemiyeti ${ }^{12}$ olarak değiştirmiştir.

Suriye ile Fransa arasındaki antlaşmayı imzalayan Suriye heyetinin başkanı Haşim Attami ${ }^{13}$, Fransa'dan Suriye'ye dönüşünde İstanbul'da bir demeç vermiştir. Attami, bu demecinde, Fransız idaresi altında özerk bir yönetimin sürdüğü Antakya ve İskenderun'un Suriye Devleti'ne devrinden sonra da aynı hukuk ve salahiyetlerini

\footnotetext{
${ }^{10}$ Cumhuriyet, 13 Eylül 1936.

${ }^{11}$ Atatürk'ün Söylev ve Demeçleri I-III, Derleyen: Nimet Arslan, Ankara, 1997,

s. 410; Dayı, a.g.m., s. 334; Saygı, a.g.m., s. 169.

${ }^{12}$ Aydın, a.g.m., s. 145; Atabey, a.g.m., s. 195.

${ }^{13}$ Cumhuriyet Gazetesi'nde Haşimül Etasi olarak geçiyor. Bkz. Cumhuriyet, 24 Eylül 1936.
}

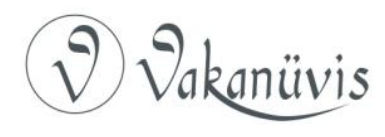


sürdüreceğini ifade ederek $^{14}$, Türkiye'nin konuyla ilgili tepkisini yatıştırmaya çalışmıştır. Bununla birlikte, bu süreçteki Türk basını takip edildiğinde, kendisinin açıklamalarının Türk tarafında herhangi bir yatışma sağlamadığı da görülmektedir.

Nitekim, Cumhuriyet Gazetesi'nde yayınlanan haberde, Attami'nin demecinin yanında, demece cevaben, Türkiye'nin en başından beri manda yönetimlerine karşı olduğu, Suriye'deki Fransız mandasına karşı çıktığı gibi, İskenderun'daki Suriye mandasına da karşı çıkacağı belirtilmekteydi. 25 Eylül tarihli ve Falih Rıfkı Atay imzalı haberde de Fransa ile Suriye arasında Türkiye'nin haberi olmaksızın imzalanan antlaşma ve Attami'nin demeci eleştirilmiştir. Atay, 250 bin kişilik Türk nüfusunun akıbetinin unutulmuş olmasının üzücü olduğunu ifade etmiş, dünya barışının sağlanması için ulusların bağımsızlığını savunan Türkiye'nin, Suriye'nin bağımsızlığını kazanmasını sevinçle karşıladığını belirtmiştir. Attami'nin verdiği demeçle ilgili olarak da, Hatay Sancağı'ndaki Türk nüfusunun bir azınlık olarak görülemeyeceğini ve Sancak halkının da Suriyeliler gibi bağımsız olmaları gerektiğini ifade etmiştir ${ }^{15}$. Atay'ın bu yazısında, Hatay'ın bağımsız olması gerektiğine ilişkin beklenti, ele alınan iki gazetede Sancak Sorunu ile alakalı haberler içerisinde ilk kez ifade edilmiştir.

\section{Uluslararası Mesele olarak Sancak}

1921 yılında Türkiye ile Fransa arasında imzalanan Ankara Antlaşması'nın çifte garantörlük ilkesine rağmen, Fransa'nın Türkiye'nin görüşünü sormadan Suriye ile böyle bir antlaşma imzalaması ve Hatay'ı Suriye'ye devretmesi üzerine, Türk hükümeti hemen itiraz hakkını kullandı ve durumu Milletler Cemiyeti'ne taşıdı ${ }^{16}$. Böylece Fransa'nın Suriye ile yapmış olduğu tek yanlı antlaşma ile Hatay Sorunu uluslararası bir platforma taşınmış oldu.

Sancak Sorunu ile ilgili müzakereler, Milletler Cemiyeti'nin 26 Eylül 1936 tarihli toplantısıyla başladı. Müzakerelere Türkiye'yi temsilen katılan Dışişleri Bakanı Tevfik Rüştü Aras, İskenderun ve Antakya halkının kendi işlerini yürütme hakkının sağlanması ve İskenderun

\footnotetext{
${ }^{14}$ Ulus, 23 Eylül 1936; Cumhuriyet, 24 Eylül 1936.

${ }^{15}$ Ulus, 25 Eylül 1936.

${ }^{16}$ Melek, a.g.e., s. 2; Atabey, a.g.m., s. 196.
}

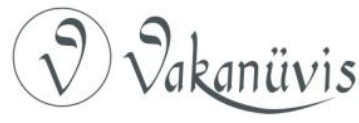


Sancağı'na bağımsızık verilmesi fikrini savundu ${ }^{17}$. Ancak Milletler Cemiyeti, bu konuda kesin bir karar almadı ve konunun Türkiye ile Fransa arasında müzakere edilmesini kararlaştırdı ${ }^{18}$. Cenevre'de yapılan bu görüşmeler, Suriye basınında tepkiyle karşılandı. Ulus Gazetesinin 29 Eylül tarihli sayısında, Suriye basınında Türkiye'nin çabalarını ve Tevfik Rüştü Aras'ı eleştiren yazılar çıktığı ifade edilmektedir ${ }^{19}$. Türkiye tarafının Sancak Sorunu'nu uluslararası platforma taşıması ve Sancak'ın bağımsız olmasına ilişkin açıklamalarının, Suriye tarafından eleştirilmesi, Türk basınını da harekete geçirmiş ve kardeşlik vurguları yapılarak sorunun çözümüne ilişkin öneriler sunulmuştur.

Bu çerçevede, 30 Eylül'de Ulus gazetesinde yayınlanan bir haberde, Türkiye-Suriye dostluğu ve kardeşliğine atıflarda bulunularak, Suriye'nin bu dostluğa uygun hareket etmesi ve Sancak'ın bağımsız bir devlet olmasını kabul etmesi istenmiştir. Sancak Sorunu'nun Fransa'nın tutumundan kaynaklandığının ifade edildiği yazıda, İskenderun-Antakya Sancağı'nın Fransa'nın tek taraflı tasarrufu ile Suriye'ye bağlanmasının 1921 antlaşmasına aykırı olduğu ve bunun bir hukuk ihlali olduğu da vurgulanmaktadır ${ }^{20}$. Türkiye'nin uluslararası girişimlerinin Suriye kamuoyunda yarattığı tepkiye karşılık, Türk basını durumun hukuksuzluğunu ve iki ülkenin kardeşliğini vurgulayarak, bu sorunla ilgili Fransa'nın suçlu olduğunu belirtmiştir.

Türk Hükümeti, 10 Ekim 1936 tarihinde, Paris büyükelçiliği aracılığıyla, Fransız Hükümeti'ne bir nota vermiştir. Bu notada, Fransa'nın Suriye ile yapmış olduğu antlaşmayla aynı nitelikte bir antlaşmayı İskenderun Sancağı'yla da yapması ve Sancak halkına kendi kendini idare etme hakkı verilmesi istenmiştir. Fransa, 10 Kasım tarihinde Türkiye'nin notasına olumsuz cevap vermiştir ${ }^{21}$. Türkiye'nin Fransa'ya konuyla ilgili nota verdiği, 12 Ekim tarihinde Ulus ve Cumhuriyet gazetelerinde duyurulmuştur ${ }^{22} .25$ Kasım tarihinde ise iki

\footnotetext{
${ }^{17}$ Cumhuriyet, 29 Eylül 1936.

${ }^{18}$ Tayfur Sökmen, Hatay'ın Kurtuluşu Için Harcanan Çabalar, Ankara, 1978, s. 6-7; Ada, a.g.e., s. 111.

${ }^{19}$ Ulus, 29 Eylül 1936.

${ }^{20}$ Ulus, 30 Eylül 1936.

${ }^{21}$ Sökmen, a.g.e., s. 7.

${ }^{22}$ Ulus, 12 Ekim 1936; Cumhuriyet, 12 Ekim 1936.
}

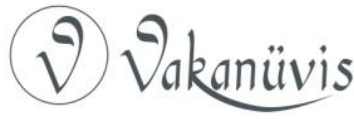


ülke arasında karşılıklı olarak alınıp verilen notaların metinleri yayınlanmıştır ${ }^{23}$. Türk tarafının bu girişimi, Milletler Cemiyeti'nin sorunun iki devlet arasında çözümlenmesine ilişkin kararının uygulanamayacağının da bir göstergesi olmuştur.

Atatürk'ün, 1 Kasım tarihinde TBMM'nin 5. dönem 2. toplantı yılını açarken yaptığı konuşma metni, 2 Kasım tarihli Ulus ve Cumhuriyet gazetelerinde yayınlamıştır. Atatürk, konuşmasında, Türkiye'yi meşgul eden en önemli sorunlardan birinin halkı Türk olan İskenderun-Antakya bölgesinin geleceği olduğunu belirterek, bu sorunun Fransa ile Türkiye arasındaki tek sorun olduğunu ve üzerine büyük bir ciddiyet ve katiyetle gidilerek bu sorunun çözüleceğini ifade etmiştir ${ }^{24}$. Atatürk, Fransa ile diplomatik ilişkilerin normalleşmesini istiyor ve bunun için de Sancak Sorunu'nun ortadan kalkmasını istiyordu. Buna karşılık, Fransa'da da Atatürk'ün bu düşüncesini destekleyen haberler yayınlanmaktaydı.

Örneğin, Fransa'nın La Republique gazetesinde yayınlanan 2 Eylül tarihli ve "Fransa Sancak Türklerini Düşünmeli" başlıklı makalede, Türkiye-Ingiltere yakınlaşmasına değinilerek, İngiltere'nin güçlü Atatürk yönetimiyle yakınlaşmasının, bu ülkeye Akdeniz'de politik bir başarı sağladığı vurgulanmış ve Fransa'nın doğudaki çıkarlarını düşünerek, Türkiye ile yakınlaşması gerektiği ifade edilmiştir. Makaleye göre, bu yakınlaşmanın sağlanabilmesi için Fransa'nın Hatay Sorunu'yla ilgilenmesi gerekmekteydi ${ }^{25}$. Ancak Fransa, bu sırada Suriye ile yaptığı

${ }^{23}$ Ulus, 25 Kasım 1936.

24 Ulus, 2 Kasım 1936; Cumhuriyet, 2 Kasım 1936; Atabey, a.g.m., s. 195. TBMM 5. Dönem 2. Yasama yılı tutanakları incelendiğinde, Atatürk'ün yaptığı açılış konuşmasında Hatay ile ilgili herhangi bir kayda rastlanmamıştır. Bununla birlikte Atatürk, Türkiye'nin barış ülküsüne bağlı kaldığını ve bu konuda da Milletler Cemiyeti'nin tecrübelerinden istifade edileceği ve bu barışın güçlendirileceğini belirtmiştir. Bu çerçevede, Hatay sorununu barış̧̧ı yöntemlerle çözmek amacında olduğu ifade edilebilir. Bkz. TBMM Zabıt Ceridesi, 6. Cilt (5. Dönem, 2. Yasama Yılı), 1 Kasım 1935, https://www.tbmm.gov.tr/tutanaklar/TUTANAK/TBMM/d05/ c006/tbmm05006001.pdf.

${ }^{25}$ Ulus, 7 Kasım 1936.

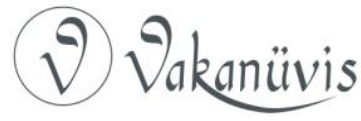


antlaşmaya gereğince, Suriye seçimlerini yaptırmakla meşguldü ve bu nedenle de Hatay'ın geleceği konusunda bir adım atmak istemiyordu.

\section{Suriye'de Seçimler ve Sancak}

Sancak'ta yaşayan Türkler, Suriye'de 17 Kasım'da yapılması planlanan seçimlere katılmama ve bütün baskılara rağmen bu karara uyma kararı almışlardır ${ }^{26}$. Bu karar, Türk basınında yoğun bir şekilde işlenmiş ve büyük bir yankı bulmuştur. 16 Kasım tarihli Ulus ve Cumhuriyet gazetelerinde yer alan haberlerde, Sancak halkının \%90'ının (sadece Türkler değil, aynı zamanda Ermeniler, Aleviler ve Çerkesler) seçime katılmayacakları, silahlı jandarmaların köylüleri zorla (elini kolunu bağlayarak, dayak atarak) sandık başına götürmeye çalıştıkları, zulümden kaçanların jandarmalar tarafından öldürüldüğü, minarelere makineli tüfekler yerleştirildiği, Antakya'da çıkan Yenigün gazetesinin kapatıldığı, Türklerin dükkânlarını kapatarak veya memuriyetlerinden istifa ederek seçime katılmamak için evlerine kapandıkları ve vatansever Türklerden bazılarının sancaktan uzaklaştırıldıkları aktarılmıştır ${ }^{27}$. 17 Kasım tarihli haberde, bütün işkencelere rağmen bir tek Türk'ün bile sandığa gitmediği, koca şehirde 77 Sünni, 37 Alevi ve 76 Hıristiyan ve Ermeni'nin oy verdiği bu başarısızlık nedeniyle İskenderun'daki Fransız vekilin istifa ettiği belirtilmiştir ${ }^{28}$. Seçimlerden 4 gün sonra yayınlanan haberde ise, Suriye seçimlerinde, Antakya'daki 40.000 Türk arasından sadece 190 kişinin oy kullandığı açıklanmıştır ${ }^{29}$. Gerek Fransız temsilcisinin ve gerekse Suriyeli yetkilerin Türk halkını kışkırtma çabaları sonuç vermemiş, Türk vatandaşlar tepkilerini seçimlere katılmayarak göstermişlerdir. Yapılan bütün zulümlere karşı dik durmuşlar ve sandığa gitmemişlerdir.

İskenderun Sancağı'nda ikinci derece seçimler, Fransız askerlerinin gölgesinde, 30 Kasım'da gerçekleştirilmiştir. Türklerin boykotu ve Fransızların hile ve baskıları sonucunda, Antakya'dan iki Arap mebus seçilmiştir. Ancak bu durum Sancak'taki olayların artmasına ve taraflar

\footnotetext{
${ }^{26}$ Ihsan Güneş, Türk Parlamento Tarihi, c.1, Eskişehir, 2003, s. 552; Ulus, 15 Kasım 1936.

${ }^{27}$ Ulus, 16 Kasım 1936; Cumhuriyet, 16 Kasım 1936.

${ }^{28}$ Cumhuriyet, 17 Kasım 1936.

${ }^{29}$ Ulus, 21 Kasım 1936.
}

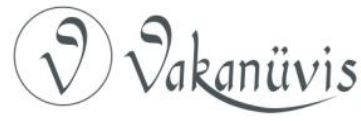


arasında çatışmalar çıkmasına neden olmuştur ${ }^{30}$. Çıkan olaylar sırasında Ermeni ve Kürtlerin silahlandırılmaları da gündeme damgasını vurmuştur $^{31}$. Hatay'da bulunan Türk Halk Mümessilleri, seçimler sırasında yaşanan bu olayların ardından, Fransa'nın Suriye Komiseri Kont de Martel'e ve Türk ve Fransız Dışişleri Bakanlıklarına seçimleri protesto eden telgraflar göndermişler ve seçilen mebusların Türk halkını temsil etmeyeceğini bildirmişlerdir ${ }^{32}$. Yaşanan tüm bu gelişmelerin ardından, Türk Hükümeti, sorunu tekrar uluslararası alana taşımak zorunda kalmıştır.

Bu çerçevede Türk Hükümeti, 8 Aralık 1936 tarihinde Sancak sorununu yeniden Milletler Cemiyeti'nin gündemine taşımıştır ${ }^{33}$. Milletler Cemiyeti'ne sunulan raporda, Hatay üzerindeki anlaşmazlıkların giderilmesine ilişkin öneriler sunulmuş ve Hatay'daki halkın can ve mal güvenliğinin tehlike altında olduğu belirtilerek duruma müdahale edilmesi istenmiştir ${ }^{34}$. Milletler Cemiyeti, konuyu 14-15 Aralık tarihli toplantısında müzakere etmiştir. Toplantıda Türk heyeti, Sancak'ta huzurun ve asayişin sağlanması için Fransız askerlerinin çekilmesini ve bölgeye Milletler Cemiyeti'ne bağıı tarafsız askerler gönderilmesini talep etmiştir ${ }^{35}$. Türkiye'nin istediği asıl çözüm, Fransa'nın Suriye ve Lübnan'la yapmış olduğu antlaşmalarla aynı nitelikte bir antlaşmayı da Sancak'la da yapması ve Sancak'a bağımsızık verilmesiydi. Ancak Fransa, Türkiye'nin tekliflerini kabul etmemiştir.

Fransa, sancak sorununun Türkiye ile Fransa arasında görüşülmesini ve tarafsı bir heyetin bölgeye giderek incelemelerde bulunmasını teklif

\footnotetext{
${ }^{30}$ Sökmen, a.g.e., s. 8; Cumhuriyet, 5 Aralık 1936.

${ }^{31}$ Ulus, 4 Aralık 1936. 3 Aralık tarihli bir haberde, sancakta ikinci tur seçimler sırasında, hiçbir Türk'ün canının ve malının güvende olmadığı, zulüm ve işkencenin tahammül edilemez bir hal aldığı, Fransız askerlerin köyleri basarak halkın elinde avucunda ne kaldıysa el koydukları ifade edilmektedir. Bkz. Cumhuriyet, 3 Aralık 1936.

${ }^{32}$ Ulus, 5 Aralık 1936.

${ }^{33}$ Ulus, 10 Aralık 1936.

${ }^{34}$ Cumhuriyet, 10 Aralık 1936; Dayı, a.g.m., s. 335.

${ }^{35}$ Yusuf Sarınay, "Atatürk Dönemi Türk Dış Politikası ve Hatay”, Anavatana Katılışının 60. Yıldönümünde Hatay, Ankara, 2001, s. 34; Ada, a.g.e., s. 120121; Tekin, a.g.e., s. 222.
}

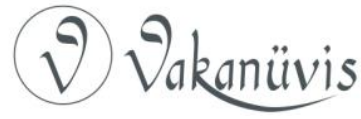


etmiştir. Milletler Cemiyeti bu teklifi kabul etmiş ve Norveç, İsveç ve Hollanda temsilcilerinden oluşan bir komiteyi gözlemci olarak sancağa gönderme ve bu süreçte Sancak'taki Fransız takviye kuvvetlerinin geri çekilmesi kararı almıştır ${ }^{36}$. Gözlemcilerin Antakya'ya gelmesinin ardından, Suriye yanlısı Araplar, gözlemcileri etkilemek için gösteriler yapmışlardır $^{37}$. Aynı zamanda Fransız basını, Sancak'ta Türklerin çoğunlukta olmadıklarına ve şehirde hiçbir tazyik ve işkencenin yaşanmadığına ilişkin haberler yayınlamaya başlamışlardır ${ }^{38}$. Tüm bu çabalara rağmen, Türkiye'nin sorunu uluslararası boyuta taşıma politikası böylece meyvelerini vermeye başlamış ve Milletler Cemiyeti her ne kadar sorunun iki ülke arasında görüşülmesini istemiş olsa da, bölgeye heyet göndererek bu soruna iştirak edeceğinin de sinyallerini vermiştir.

\section{Sandler Raporu ve Sancak'ın Bağımsızlığını Kazanma Süreci}

Fransa, Türkleri Hatay'da bir azınlık olarak görmekteydi. Fransızlar, İskenderun Sancağı' nın nüfusunu 190.000 olarak kabul ediyor ve bunun sadece 70.800 'ünün Türk olduğunu iddia ediyordu. Ancak Fransa, bu rakamlara bir nüfus sayımı yaparak ulaşmamış, hatta medeni kanunun gerektirdiği sayımlar son 15 yıldır yapılmamıştı. İskenderun nüfusu o tarihte yaklaşık 300.000 civarındaydı ve aradaki fark da Türklerden oluşmaktaydı $^{39}$. Fransızlar, nüfus istatistiklerinde Türkleri azınlık göstererek, bölgeyi kendi çıkarları doğrultusunda şekillendirmeyi hedeflemekteydi.

Milletler Cemiyeti'nin Sancak'a görevlendirdikleri tarafsız heyet, 4 Ocak 1937 'de i̇skenderun'a vararak çalışmalarına başlamışlardır. Çektikleri sıkıntıları ve yaşadıkları zulmü anlatmak için binlerce kişi, heyetin konakladığı Durieux'un evine doğru giderken, jandarma ve polis kuvvetleri yollarını kesmiş ve silah kullanarak kalabalığı dağıtmıştır ${ }^{40}$. Sancak'ta yaşanan zulüm ve işkencelerin devam etmesi üzerine, Atatürk, 7 Ocak 1937 tarihli Bakanlar Kurulu toplantısında,

\footnotetext{
${ }^{36}$ Ulus, 18 Aralık 1936; Cumhuriyet, 18 Aralık 1936, Dayı, a.g.m., s. 335.

${ }^{37}$ Tekin, a.g.e., s. 223.

${ }^{38}$ Cumhuriyet, 18 Aralık 1936.

${ }^{39}$ Ulus, 5 Ocak 1937.

${ }^{40}$ Cumhuriyet, 7 Ocak 1937.
}

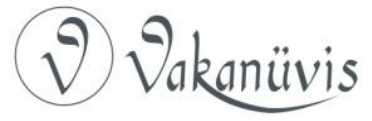


Hatay Sorunu'nu kendi şahsi meselesi olarak kabul ettiğini, bu meselenin silahlı bir mücadele yoluyla çözülemeyeceğini belirtmiş ve gerekirse cumhurbaşkanlığından ve meclis üyeliğinden istifa ederek, Hatay'a gideceğini ve Hatay halkı ile birlikte mücadele edeceğini ifade etmiştir ${ }^{41}$. Atatürk'ün Ocak 1937'deki Konya ve Eskişehir gezilerinin ardından ${ }^{42}$, Hatay'da Türklere yapılan baskı ve şiddet uygulamaları dünya basınında tartışılmaya başlanmıştır.

Türklerin Hatay'da başlattığı grev, Türklerin düzenledikleri gösteriler sırasında tarafsız gözlemcilerin önünde bile Türklerin öldürülmesi ${ }^{43}$ ve Halk Mümessillerinin Hatay'daki tarafsız gözlemcilere verdiği raporlar da olayın boyutlarını genişletmiştir ${ }^{44}$. Ulus gazetesi, 21 Ocak tarihli nüshasında, Hırvat lideri Dr. V. Maçek'in görüşlerine yer vermiştir. Habere göre, Dr. Maçek, 300.000 kişilik Türk nüfusunun İskenderun Sancağı'nda çoğunluğu teşkil etmesi nedeniyle, Türkiye'nin sancağın kendisine iade talebinden dolayı serzeniş edilmemesi gerektiğini ileri sürerek, Türklerin gerekirse silah gücüyle bu sorunu çözmeye karar verdiklerini ifade etmiştir ${ }^{45}$.

Hatay sorunundaki tutumu nedeniyle, Fransa'ya Türk basınında büyük bir tepki oluşmuştur. Cumhuriyet gazetesi başyazarı Yunus Nadi, Hatay sorununun Türkiye için bir onur meselesi hali aldığını ve Fransa'nın bunu algılayamadığını, eğer Türkiye iki ülke arasındaki dostluğa ters düşecek bir harekette bulunursa bunun sorumlusunun Fransa olacağını ifade etmiştir ${ }^{46}$. Aynı şekilde, Fransa Hükümeti'nin Sancak politikası, Fransız basını tarafından eleştiri oklarına maruz kalmaya başlamıştır. Örneğin, Liberte, Humanite, Petit Journal gazetelerinde Atatürk yönetimindeki güçlü Türk devleti ile anlaşmanın Fransa için büyük değer taşıdığı ve bu nedenle de Türk tarafının taleplerinin görmezden gelinmemesi gerektiği ifade edilmiştir ${ }^{47}$. Fransız hükümetinin izlediği politikaların iki ülke basını tarafından da

\footnotetext{
Sökmen, a.g.e., s. 9.

2 Dayı, a.g.m., s. 336.

${ }^{43}$ Cumhuriyet, 12 Ocak 1937; Cumhuriyet, 21 Ocak 1937.

${ }^{44}$ Ulus, 13 Ocak 1937.

${ }^{45}$ Ulus, 21 Ocak 1937.

${ }^{46}$ Cumhuriyet, 7 Ocak 1937.

${ }^{47}$ Ulus, 25 Aralık 1936.
}

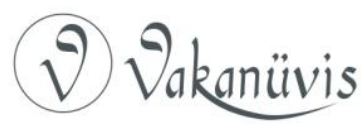


eleştirilmesine rağmen, bu süreçte, İngiliz gazetelerinde "Türkiye'nin Suriye'yi ve daha sonra da Irak'ı işgal ederek yeni bir Osmanlı İmparatorluğu kurma arzusu taşıdığı" iddialarını içeren haberler yayınlanması, Türk basını tarafından eleştirilmiştir. Bu haberlerin, propaganda amaçlı yazılar olduğu vurgulanmış ve dünyada Türkiye aleyhine kamuoyu oluşturulmaya çalışıldığı ifade edilmiştir ${ }^{48}$. İngiliz basınının Türkiye aleyhine kamuoyu oluşturma çabası, Türk hükümetinin sorunu büyük bir hassasiyetle ele alması ve uluslararasılaştırması sonucunda başarısız kalmıştır.

Gerek Fransız ve Türk basınında Hatay sorununa ilginin yoğunlaşması, gerekse Türk Hükümeti'nin kararlılığı karşısında Fransız Hükümeti'nde konuyla ilgili bir yumuşama eğilimi baş göstermiştir. Fransız Başbakanı Leon Blum, 18 Ocak 1937'de Türkiye'ye sorunun Milletler Cemiyeti'nin alacağı kararla çözülmesini kabul ettiğini bildirmiştir. Bunun üzerine konu, 20 Ocak 1937 tarihinde Cenevre'de Milletler Cemiyeti tarafından tekrar görüşülmeye başlanmıştır. İstanbul ve Ankara radyoları, Türk tezi olan konfederasyon teklifini Arapça olarak yayınlamaya başlamış ve bu teklifin Suriyeliler tarafından olumlu karşılandığı gözlemlenmiştir ${ }^{49}$. Fransız hükümetinin bu girişimi, hem iki ülke arasındaki buzları eritmiş hem de Sancak Sorunu'nun çözümü konusunda önemli bir adım olmuştur.

Milletler Cemiyeti'nin 27 Ocak 1937 tarihli oturumunda Türk ve Fransız hükümetlerinin ilke bakımından anlaştıkları metin, İsveç Dışişleri Bakanı Sandler tarafından onaya sunulmuştur. Sandler Raporu olarak adlandırılan metinde, Sancağın Milletler Cemiyeti garantisinde, içişlerinde bağımsız, dış ilişkilerinde Suriye'ye bağlı olacağı, kendi parlamentosunun, anayasasının ve hükümetinin olacağı, askerden arındırılacağı ve Türkiye ile Fransa'nın Sancağa her türlü saldırıya karşı ortak garantör olacağı vurgulanmıştır ${ }^{50}$. Böylece, İsveç ve İngiliz Dışişleri bakanlarının da imzalarının bulunduğu bu antlaşma ile Sancağa Milletler Cemiyeti'nin de garantörlüğünde bir muhtariyet verilmiş

\footnotetext{
${ }^{48}$ Ulus, 8 Ocak 1937.

${ }^{49}$ Ulus, 21 Ocak 1937; Dayı, a.g.m., s. 336.

50 Ulus, 28 Ocak 1937; Atabey, a.g.m., s. 196; Dayı, a.g.m., s. 337; Aydın, a.g.m., s. 146; Karakoç, a.g.m., s. 104-105.
}

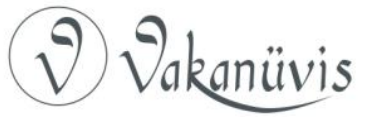


oluyordu. Sancağın güvenliği, Türk- Fransız ortak askerî komisyonu tarafından sağlanacaktı.

Milletler Cemiyeti'nin onayladığı Sandler Raporu, Türk basınında sevinçle karşılanmıştır. Ulus gazetesi başyazarı F. Rıfkı Atay, Sandler raporunu "Eser" olarak nitelemiş ve bunu da Atatürk'ün İsmet İnönü'ye gönderdiği telgrafla açıklamıştır. Atatürk telgrafında, bu eserin Türkiye'nin millî meseleler üzerinde büyük bir dikkat ve ciddiyetle durduğunu ve Türkiye'nin sorunun çözümünü Milletler Cemiyeti'ne bırakarak barışçı ve insaniyetçi politikasını kanıtladığını belirtmiştir ${ }^{51}$. Cumhuriyet Gazetesi başyazarı Yunus Nadi ise üç aydır devam eden ve zor günler yaşanmasına neden olan Sancak Sorunu'nun, "başbuğ Atatürk'ün irşadı ve işaretiyle", Türklerin memnun kalacağı bir şekilde çözümlendiğini ve bundan dolayı Türk milletinin sevinç duyması gerektiğini ifade etmiştir ${ }^{52}$.

Milletler Cemiyeti'nce kabul edilen Sandler Raporu doğrultusunda, Hatay Sancağı için anayasa hazırlanması çalışmaları, 28 Şubat 1937 tarihinde Cenevre'de başladı. Kurulan hazırlık komisyonuna Türkiye adına Dışişleri Bakanlığı Genel Sekreteri Numan Menemencioğlu, Fransa adına B. Robert de Caix ve üç yabancı uzman katıldı. Komisyonun hazırlayacağı projelerin Milletler Cemiyeti tarafından 1937 yılı Mayıs ayında görüşülmesi kararlaştırıldı ${ }^{53}$.

Cenevre'deki görüşmeler sırasında, Hatay'da bulunan tarafsız gözlemciler, raporlarını sunmak için Hatay'dan ayrılarak Cenevre'ye gittiler. Bu durum Türk basınında tepkiyle karşıland I4 $^{54}$. Türk tarafına göre, Hatay'daki gergin durum ve Suriye hükümetinin olumsuz tutumu göz önüne alındığında, tarafsız gözlemcilerin Hatay'dan ayrılması sakıncalıydı ve sadece raporlarını göndermeleri yeterli olacaktı.

Fransa, Türkiye ile görüşmelerini sürdürdüğü ve sorunun çözümü için çalıştığı izlenimleri verdiği sıralarda, Hatay'daki Türklerin bir araya gelmelerini önlemek için çeşitli tedbirler alıyordu. Bunlardan biri de etnik gruplar arasındaki çatışmaları kışkırtmaktı. Fransa, bu tür

${ }^{51}$ Ulus, 29 Ocak 1937.

${ }^{52}$ Cumhuriyet, 29 Ocak 1937.

53 Pehlivanlı, a.g.e., s. 78-79.

${ }^{54}$ Ulus, 27 Şubat 1937. 
çalışmalarını yoğunlaştırdığı Lazkiye'de, Alevileri kışkırtarak ve onların Türk, Arap veya Müslüman olmadıklarını vurgulayarak, Türklerin ve Arapların kendilerine kötü davranacakları yönünde propaganda yapmaya başlamıştı ${ }^{55}$. Fransa'nın bu tür faaliyetleri, Türkiye ve Milletler Cemiyeti'ne uzlaşmacı yaklaşımının göstermelik olduğunu ortaya koymaktaydı.

Buna tutuma karşılık olarak, Tayfur Sökmen, Fransa'nın faaliyetlerini Atatürk'e aktarmış ve Atatürk de kendisini Kilisli tarihçi Necip Asım Bey'e göndermiştir. Necip Asım, "Hasan Sabbah'ın ırkından gelen Alevilerin tamamen Türk olduklarını, ancak doğuya gidenlerin Kürtleştiklerini ve güneye gidenlerin de Araplaştıklarını, Lazkiye'den ötede bir tek Alevi olmadığını" ifade etmiştir. Daha sonra Atatürk de, Alevilerin Arap olmadıklarını, kendilerinin Eti Türklerinden olduklarını vurgulamıştır. Tayfur Sökmen ve Hatay Egemenlik Cemiyeti, Aleviler arasında karşı propaganda yaparak, kendilerinin Eti Türkü oldukları söylemiyle, Fransız propagandasını önlemeye çalışmışlardır ${ }^{56}$. Ulus gazetesinin 10 Mart tarihli sayısında, İçişleri Bakanı Şükrü Kaya'nın Adana'da yaptığı konuşmaya değinilmiştir. Şükrü Kaya, konuşmasında Alevilerin öz Türk olduklarını ifade etmiş ve Cumhuriyet Halk Partisi'nin altı okunun anlamını açıklayarak, bu tür ayrımlara karşı olduklarını belirtmiştir $^{57}$. Fransa'nın bölgede yaşayan Alevilere karşı izlediği ayrıştırmacı politikası, Atatürk'ün politik ve tarihsel manevralarıyla bastırılmıştır.

Cenevre'deki anayasa hazırlık komitesi çalışmalarından bir sonuç alamayarak, 17 Mart 1937'de dağıldı. Anlaşmazlığın temelinde Sancağın dil ve sınırlarının belirlenmesi sorunları vardı. İkinci toplantının 9 Nisan'da yapılması kararlaştırıldı. Ancak Numan Menemencioğlu'nun rahatsızlığı nedeniyle toplantı 22 Nisan'a ertelendi $^{58} .22$ Nisan'da başlayan ikinci görüşmeler olumlu sonuç verdi ve 29 Mayıs 1937 tarihinde Milletler Cemiyeti, Hatay'ın bağımsızlığını

\footnotetext{
55 Sökmen, a.g.e., s. 97.

${ }^{56}$ Sökmen, a.g.e., s. 97.

${ }^{57}$ Ulus, 10 Mart, 1937.

${ }^{58}$ Ulus, 3 Nisan 1937.
}

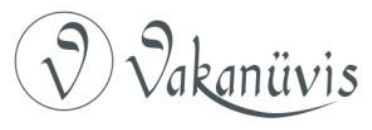


onayladı $^{59}$. Türkiye ile Fransa arasında imzalanan metne göre, Sancağın resmi dili Türkçe olacaktı ancak ikinci dil olarak Arapça da kullanılacaktı. Bu antlaşma ile İskenderun ve Antakya sancaklarının bütünlüğü garanti ediliyordu ve sınırları da tespit ediliyordu. Antlaşmayı Türkiye adına Tevfik Rüştü Aras, Numan Menemencioğlu ve Hasan Rıza Soyak, Fransa adına ise Dışişleri Bakanı Ivon Delbos, Pierre Vienot ve Türkiye Büyükelçisi Henri Ponsot imzaladı. Milletler Cemiyeti, antlaşmanın 27 Kasım'da yürürlüğe konulmasını kararlaştırdı ${ }^{60}$. Suriye meclisi, TürkFransız antlaşmasını protesto ettiyse de ${ }^{61}$ bu protestonun herhangi bir etkisi olmadı.

Antlaşma ile Suriye'ye bırakılan nahiyelerle ilgili olarak Ulus gazetesinde yayınlanan haberde, dostluk için bazı fedakârlıklar yapılmasının gerekliliğini vurgulamıştır ${ }^{62}$. Cumhuriyet gazetesi başyazarı Yunus Nadi, 23 Kasım 1937 tarihli yazısında, Atatürk'ün 14 yıl öncesinde "gözü yaşlı Hataylı genç kızlara, 4000 yıllık Türk ülkesinin esarette kalamayacağını" söylediğini hatırlatarak, bu kez aynı kızların minnet ve sevinç gözyaşı döktüklerini ifade etmiştir ${ }^{63}$.

Numan Menemencioğlu, Cenevre'den dönüşünde yaptığı basın açıklamasında, mukadderatına tamamen hâkim ve bağımsız bir Hatay'ın kurulduğunu, Türkçenin resmi dil olarak kabul edildiğini, Bayır ve Bucak nahiyelerinin Sancağa dahil edilmesinin mümkün olamadığını ancak buraların halkının da Türk dilini kullanabilme hakkına sahip olduklarını ifade etmiştir. Ayrıca Hatay anayasasının Kasım ayında yürürlüğe gireceğini, anayasanın yürürlüğe girmesinden üç-dört ay sonra seçimlerin yapılacağını, Sancağın isminin Sancak Yasama Meclisi tarafından konulacağını ve Hatay'ın istediği bayrağı seçmekte özgür olacağını belirterek yapılmış olan antlaşmayı Türk basını aracılığıyla Türk milletine duyurdu ${ }^{64}$.

${ }^{59}$ Karakoç, a.g.m., s. 106; Hatay'ın Kurtuluş Mücadelesinde Türk Ordusu, s. 174.

${ }^{60}$ Ulus, 2 Haziran 1937; Ada, a.g.e.,s. 131-137.

${ }^{61}$ Ulus, 16 Haziran 1937.

${ }^{62}$ Ulus, 30 Mayıs 1937.

${ }^{63}$ Cumhuriyet, 25 Kasım 1937.

${ }^{64}$ Ulus, 2 Haziran 1937.

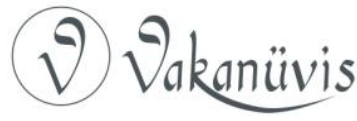




\section{Bağımsız Hatay'da Seçimler ve Hükümetin Kurulması}

Dışişleri Bakanlığı Siyasi Müsteşarı Numan Menemencioğlu, 27 Kasım 1937 'de yürürlüğe girmesi planlanan yeni statü ve yapılacak seçim çalışmalarını izlemek amacıyla Suriye'ye gitti ${ }^{65}$. Menemencioğlu, Hatay seçim komisyonunun çalışmalarını görüşmeyi hedefliyordu ancak görüşmeler sırasında hastalanarak Türkiye'ye döndü66. Milletler Cemiyeti de seçim çalışmalarını denetlemek için 20 Ekim'de Hatay'a bir komisyon gönderdi. Komisyon, seçmen listelerinde her seçmenin doğuştan mensup olduğu cemaate göre yazılmasını istedi ve bu cemaatler Türk, Arap, Alevi, Ermeni ve Rum-Ortodokslar olarak belirlendi. Böylece her cemaatin ne kadar vekil çıkaracağı tespit edilecekti ${ }^{67}$.

Hatay'ın bağımsızlığına kavuşması, Fransızların olumsuz tavır ve girişimlerinin önüne geçemedi. İlk olarak, diğer unsurları Türkler aleyhinde birleştirerek Cenevre antlaşmasının uygulanmasını engellemek isteyen Fransız delege Rajo Garo, kendisini Milletler Cemiyeti temsilcisi olarak kabul ettirme girişimlerinde bulundu ${ }^{68}$. Ardından da kutlamalar sırasında gerginlik yaratarak etnik çatışmalar çıkartmaya çalıştı. 30 Kasım tarihinde Ulus gazetesinde yer alan, "Bayrak Yerine Süngü" başlıklı yazıda, kutlamalar sırasında Fransız temsilcinin Fransız ve Suriye bayraklarının asılmasını istemesi ve Türk bayrağının asılmasına engel olmak istemesi üzerine olaylar çıktığı, Fransız askerlerinin sevinç gösterilerinde bulunan Türklere karşı süngü kullandıkları belirtilmiştir ${ }^{69}$. Cumhuriyet gazetesi başyazarı Yunus Nadi, olayların Suriyeliler tarafından çıkarıldığı imajı verilmesine rağmen, olayların sorumlusunun Fransızlar olduğunu ifade etmiş ve Türkiye'nin Fransa'yı dürüst politika sahibi bir ülke olarak görmek istediğini belirtmiştir $^{70}$. Atatürk, bu olay üzerine verdiği demeçte, Hatay'da yeni rejimin yürürlüğe girdiğini, Fransa'nın bu konuda geri adım

\footnotetext{
${ }^{65}$ Ulus, 10 Kasım 1937.

${ }^{66}$ Ulus, 14 Kasım 1937.

${ }^{67}$ Pehlivanlı, a.g.e., s. 96.

${ }^{68}$ Ulus, 29 Kasım 1937.

${ }^{69}$ Ulus, 30 Kasım 1937.

${ }^{70}$ Cumhuriyet, 30 Kasım 1937.
}

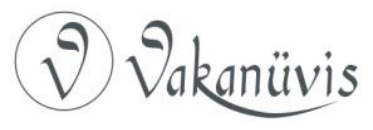


atamayacağını vurgulamıştı ${ }^{71}$. Fransa, Hatay'dan çekilmesi durumunda büyük sorunlar çıkacağı izlenimi oluşturmaya çalışıyordu.

2 Aralık tarihinde İstanbul'da Hatay için büyük bir gösteri düzenlendi. Gösteride, Hatay seçim yönetmeliğinin Türklerin aleyhine olması, Milletler Cemiyeti nezdinde protesto edildi. 87 maddelik seçim yönetmeliğinin Fransız yöneticilerle birlikte düzenlenmesine rağmen, Türkiye'ye sadece bilgi mahiyetinde bir açıklama yapıldı. Bunun üzerine Türkiye, 1926 yılında Fransa ile yapmış olduğu Dostluk Antlaşmasını tek taraflı olarak feshetti ${ }^{72}$. Fransa'nın Hatay'da kalmak adına izlediği politikalara karşı Türk hükümeti, Fransa ile dostluk antlaşmasını iptal etmesinin ardından Türkiye-Suriye yakınlaşmasını başlatarak, Fransa'yı Hatay'da devre dışı bırakmaya çalıştı.

Bu çerçevede, 21 Aralık 1937 tarihinde Suriye Başbakanı Cemil Mardam, Ankara'ya geldi. Ziyaret üzerine gazetelerde Türkiye-Suriye dostluğunu işleyen yazılar yayınlanmaya başladı. 21 Aralık tarihli Cumhuriyet Gazetesi'nde Hatay sorununun Türkiye ile Suriye'nin arasını açacak bir mesele olmadığı, Türkiye'nin Hatay'ı ilhak etmek istemediği ve bağımsız Hatay'ın Türkiye ile Suriye arasında bir köprü vazifesi göreceği ifade edilmiştir ${ }^{73}$. Türkiye-Suriye yakınlaşmasının sonucu olarak 1938 yılının Mart ayında Hatay'da seçim kayıt işlemleri, başladı.

Seçmen kayıtlar sonucunda Türklerin sancaktaki nüfus üstünlüğü net bir şekilde ortaya çıktı. Bunun üzerine Fransa'nın da desteğiyle Araplar, Türklere karşı saldırgan bir tutum izlemeye başladılar. Artık gazetelerde, Hatay'dan gelen ölüm, yaralanma ve tecavüz haberleri yayınlanmaya başladı ${ }^{74}$. Fransız jandarmaları olayların faillerini yakalıyor ancak her seferinde ceza vermeden salıveriyorlardı. Türklerin Milletler Cemiyeti komisyonunun temsilcileriyle görüşmeleri de sürekli olarak tehdit ve şiddetle engelleniyordu. Eylemlerin artması üzerine şehir esnafı mağazalarını kapatmaya başladı. Fransa ve Suriye'nin oyunlarının Türklerin sancaktaki başarısını engelleyemeyeceği aşikârdı.

${ }^{71}$ Ulus, 1 Aralık 1937.

${ }^{72}$ Ulus, 16 Aralık 1937.

${ }^{73}$ Cumhuriyet, 21 Aralık 1937.

${ }^{74}$ Ulus, 2 Mart 1938, 7 Mart 1938, 1 Haziran 1938.

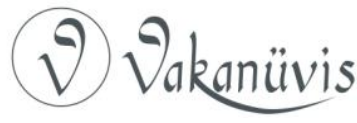


Bu nedenle de Sancak halkından sürekli olarak sandık başına gitmeleri ve tahriklere kapılmamaları isteniyordu ${ }^{75}$.

Yunus Nadi, 28 Mayıs 1938 tarihli Cumhuriyet gazetesinde yazdığı "Hatay ve Suriye Meselesi" başlıklı yazısında, Hatay meselesini Türklerin halledeceğini, Türkiye'nin konuyu Milletler Cemiyeti'ne taşıyarak dürüstlük örneği gösterdiğini, İngiltere'nin Irak'ta uyguladığı insanî yönetimi, Fransa'nın Suriye'de sergileyemediğini ve Fransız yönetiminin vahşetin modern şekli olduğunu ifade etmiştir ${ }^{76}$.

Fransızların yaptıkları uygulamaları açıklaması için Ankara'ya çağrılan Fransız delegesi Garo, Türkiye'nin istekleri doğrultusunda tam tarafsızlık göstereceklerini ifade etmesine rağmen, Sancağa döner dönmez, yayın yapan Türk gazetelerini kapatmış ve geceleri şehirlerarası yolculukları yasaklamıştır ${ }^{77}$. Böylece Sancakta bir nevi olağanüstü hal ilan edilmiş oluyordu.

Sancak'ta seçim işleri 15 Mayı 1938'de başladı. Milletler Cemiyeti'nin Türk tarafının isteyen kişinin istediği cemaate katılmakta özgür olması teklifini onaylaması üzerine, Sancak'ta Türk halkı üzerindeki baskı yoğunlaştı. Sancakta olayların artması üzerine Atatürk, 24 Mayıs'ta Adana, 29 Mayıs'ta da Mersin'i ziyaret etti ve askeri birlikleri denetledi ${ }^{78}$. Atatürk, Sancak sınırlarındaki askeri birliklerini bizzat denetleyerek, Fransa'ya gözdağı vermiş ve bu hareketin ardından Hatay'daki Fransız memurları Türklere karşı uyguladıkları politikayı sonlandırmışlardır.

Hatay'da seçim işlemleri, 3 Haziran 1938 tarihinde bir hafta süre ile durduruldu. Bu süreçte, Fransız temsilci Garo görevden alındı ve yerine Binbaşı Colle seçimler süresince temsilci olarak atandı. Bu olaylar üzerine, Türkiye ile Fransa arasında, Paris'te diplomatik ve Hatay'da ise askeri müzakereler yeniden başladı. Görüşmelerin ana çerçevesi, Cenevre Antlaşması'nın Sancak'ın tamamını garanti altına alan hükümlerine açıklık getirmekti. Ancak bu sırada Hatay'da bir Türk şoförün öldürülmesi üzerine, Ittihad-ı Vatan ve Usbe cemiyetlerinin

${ }^{75}$ Ulus, 8 Mayıs 1938.

${ }^{76}$ Cumhuriyet, 28 Mayıs 1938.

77 Ulus, 1 Haziran 1938.

78 Ulus, 30 Mayıs 1938; Atabey, a.g.m., s. 198; Ada, a.g.e., s. 166-168.

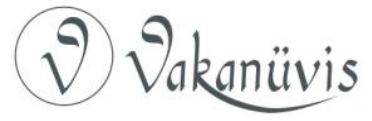


bazı üyeleri tutuklandı. Bu tutuklamaların ardından bazı gruplar hükümet konağını kuşatıp taşa tuttular. Hükümet konağını kuşatanlar arasında Milletler Cemiyeti Komisyonu başkanının da bulunması taraflar arasındaki gerginliği iyice arttırdı. F. Rıfkı Atay, bu olayı değerlendirirken, Türklerin Milletler Cemiyeti ile olan münasebetlerinin ve hatta cemiyetteki üyeliğinin yeniden düşünülmesi gerektiğini ifade etmiştir ${ }^{79}$. Bu olaylarla ilgili Yunus Nadi'nin "Klasik bir Sanat, Unsurlar Arasında Tahrik" başlıklı yazısında, Osmanlı Devleti zamanından beri ayrılıkçı unsurlar arasında yapılan tahriklere ve bunların acı sonuçlarına değinerek, şimdi aynı olayların Hatay'da çıkarılmaya çalışıldığını, bu nedenle de Türk, Ermeni, Rum, Yahudi bütün insanların bu tahriklere kapılmaması gerektiğini vurgulamıştır ${ }^{80}$.

Türk Hükümeti çıkan olaylar karşısında 20 Haziran'da toplandı. Başbakan Celal Bayar, "Hatay meselesinin bir hafta on güne kadar kesin olarak" çözümlenebileceği açıklamasını yaptı ${ }^{81}$. Türk Hükümeti, Milletler Cemiyeti Genel Sekreterliğine bir nota vererek komisyon ile ilişkilerini kesti ${ }^{82}$. Peyami Safa, 23 Haziran tarihli yazısında, Milletler Cemiyeti'nin anlamını yitirdiğini ve cemiyete inanan tek devlet kalmadığını, Hatay Sorunu'nu Türkiye'nin kendi başına halletmesi gerektiğini ifade etmiştir ${ }^{83}$. Milletler Cemiyeti, ortaya çıkan sorun üzerine, Hatay'daki komisyonu geri çekti ve sorunun doğrudan doğruya Türkiye ile Fransa arasında çözülmesine karar verdi ${ }^{84}$. İi ülke arasında görüşmeler 3 Temmuz'da sonuçlandı. Yapılan askeri anlaşmaya göre, Hatay'da Fransız askerî birliği 2500 kişiyi geçmeyecek ve Türkiye de Hatay'a 2500 kişilik bir kuvvet gönderebilecekti. Birliklerin komutanlığı Fransız makamlarına bırakılacaktı ${ }^{85}$. 5 Temmuz 1938 tarihinde Albay Şükrü Kanatlı komutasındaki Türk askerî birliklerinin Hatay’a girmesi üzerine Türkiye ve Hatay'da bayram sevinci yaşandı ${ }^{86}$. Türk ordusunun

\footnotetext{
${ }^{79}$ Ulus, 16 Haziran 1938.

${ }^{80}$ Cumhuriyet, 17 Haziran 1938.

${ }^{81}$ Ulus, 21 Haziran 1938.

${ }^{82}$ Ulus, 22 Haziran 1938.

${ }^{83}$ Cumhuriyet, 23 Haziran 1938.

${ }^{84}$ Ulus, 27 Haziran 1938.

${ }^{85}$ Ulus, 3 Temmuz 1938; Ada, a.g.e.,s. 171-172.

${ }^{86}$ Ulus, 5 Temmuz 1938.
}

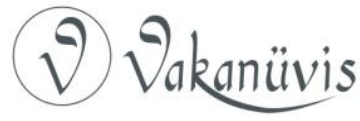


Hatay'a girmesi, Hatay'daki statüyü tamamen değiştirdi ve seçim çalışmaları sorunsuz bir şekilde yürütülmeye başlandı.

F. Rıfkı Atay, 7 Temmuz'da Ulus Gazetesi'ndeki "Kati Safha” başıklı yazısında, Hatay'ın Türk inkılâbının en eski meselesi olduğunu belirterek, Türkiye'nin artık barış̧̧ bir devlet olmaktansa emperyalist olmayı tercih ettiği yönündeki eleştirilere cevaben, Türkiye'nin Hatay sorununu barış usullerine göre çözmek konusunda, sabrını taşıran bütün tahriklere rağmen, başarılı olduğunu belirtmiştir. Atay, sorunun çözülmesini, "iki işi beraber yürüttük, sulh kadar kendi hakkımızı, hakkımız kadar sulhu müdafaa ettik" sözleriyle ifade etmiştir ${ }^{87}$.

22 Temmuz 1938 tarihinde Hatay'da seçim çalışmaları yeniden başladı. Önceden yapılan kayıtlar gözden geçirildi ve 31 Temmuz'da tescil işlemleri sona erdi. Türklerin listesi oyların \%60'ını kazanarak 40 milletvekilliğinden 22'sini aldı. 3 Ağustos tarihli Ulus gazetesinin haberine göre, seçim komisyonunun raporu şu şekildeydi:

Kaydedilen Seçmen Sayısı:

Türk Cemaati

Alevi Cemaati

Ermeni Cemaati

: 5.504

Arap Cemaati

: 1.845

Rum- Ortodoks C.

: 2.098

Diğer Cemaatler

: 359

Toplam Seçmen

: 56.972

Milletvekilliği Dağılımı:

Türk Cemaati

Alevi Cemaati

$: 9$

Ermeni Cemaati

$: 5$

Arap Cemaati

Rum- Ortodoks C.

$: 2$

Toplam

$: 40^{88}$

${ }^{87}$ Ulus, 7 Temmuz 1938.

${ }^{88}$ Ulus, 3 Ağustos 1938.

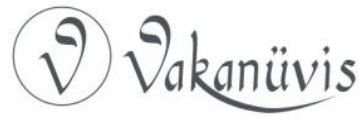


Hatay Meclisi, 2 Eylül 1938 tarihinde açıldı. İlk oturumda yapılan seçimle, Tayfur Sökmen devlet başkanı, Abdulgani Türkmen de meclis başkanı seçildi ${ }^{89}$. En yaşlı üye sıfatıyla Mehmet Adalı'nın yaptığı açılış konuşmasında, 19 yıl süren acılar dile getirilmiş ve komşu devletler olan Suriye, Lübnan ve Irak'a iyi niyet dilekleri iletilmiştir. Mehmet Adalı konuşmasını Türk milletine, Türk hükümetine ve Atatürk'e şükran ve bağlılığını ifade ederek bitirmiştir ${ }^{90}$. Seçimin Türklerin büyük başarısı ile sona ermesinde en büyük payın Fransa'nın tahriklerine kapılmadan hem uluslararası politikaya uygun davranan hem de geri adım atmayarak kararlılığını ortaya koyan Atatürk'ün önderliğindeki Türk hükümeti olduğu aşikardı.

Bu nedenle, Hatay devlet başkanı seçilen Tayfur Sökmen, Atatürk'e bir teşekkür telgrafı göndermiştir. Sökmen, telgrafında, Hatay devlet reisliğine seçildiğini belirterek, Hatay'ın bağımsızlığını, Türkiye'nin ulu önderinin çabaları sayesinde kazandığını, bu nedenle kendisine minnet, şükran ve bağlılık duyguları beslediğini, görevi sırasında Atatürk'ün kendisine yol göstermesi arzusunda olduğunu ifade etmiştir ${ }^{91}$. Atatürk, Tayfur Sökmen'in telgrafına cevaben gönderdiği telgrafta, devlet reisliğine seçildiği için memnun olduğunu belirterek kendisini tebrik etmiş ve Hatay'daki faaliyetlerinde kendisine başarılar dilemiştir ${ }^{92}$.

Sökmen, ilk iş olarak, hükümet başkanlığına Abdurrahman Melek'i atadı. Daha önceden Hatay valiliği görevi de yapmış olan Melek, İçişleri, Dışişleri ve Savunma bakanlıklarını da üstlendi. Adliye Bakanlığına Cemil Yurtman, Iktisat, Maliye ve Gümrük Bakanlığına Cemal Baki, Bayındırlık ve Ziraat Bakanlığına Kemal Alper, Eğitim ve Sağlık bakanlıklarına da Ahmet Faik Türkmen getirildi. 8 Eylül 1938 tarihinde Hatay Meclisi, Türk İstiklal Marşı'nı Hatay Marşı olarak kabul etti ${ }^{93}$.

Türklerin seçimlerdeki başarısını gölgelemek için ortaya atılan Türklerin Araplara karşı baskı uyguladığı iddiaları üzerine, Tayfur Sökmen, Lübnan'ın Ebabil gazetesi muhabirine bir demeç vererek,

\footnotetext{
${ }^{89}$ Karakoç, a.g.m., s. 109.

90 Ulus, 5 Eylül 1938.

${ }^{91}$ Ulus, 5 Eylül 1938.

92 Sökmen, a.g.e., s. 108-108.

93 Ulus, 9 Eylül 1938.
}

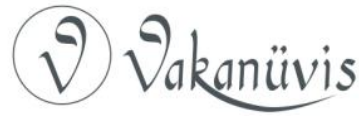


Atatürk'ün kendisine Suriye ve Lübnan'la dostane ilişkiler kurmasını tavsiye ettiğini, Hatay'da devlet işlerini idare ederken unsur, din ve mezhep farkı gözetmeksizin adaletle hareket etmesini istediğini belirterek bu suçlamaların doğru olmadığını ifade etmiştir ${ }^{94}$. Sökmen, görevine başlar başlamaz, Atatürk'ün "Yurtta barış, dünyada barış" politikasını uygulamaya koymuştur.

\section{Hatay'ın Anavatana Bağlanması}

Hatay Devlet Başkanı Tayfur Sökmen, Türkiye'de yapılan 26 Mart 1939 seçimlerinde Antalya milletvekilliğine, Hükümet Başkanı Abdurrahman Melek ise Antep milletvekilliğine seçildi. Sökmen ve Melek, Ankara'ya gelerek TBMM'nin çalışmalarına katıldılar. 1939 yılında Avrupa'da yaşanan gelişmeler ve gerginlik nedeniyle Avrupa devletleri Hatay meselesini bir kenara bırakarak kendi meseleleriyle uğraşmaya başlamıştı. Bu nedenle de Sökmen ve Melek'in Türkiye'de milletvekili olmaları Avrupa kamuoyunda yankı bulmadı. Sökmen, Antalya Milletvekili olarak Hatay'a dönüşünde bir konuşma yaparak, Hatay'ın ve Hataylıların anavatandan ayrı yaşamaya tahammül edemediklerini $^{95}$ ifade ederek Hatay'ın anavatana bağlanma sürecini başlattı.

Avrupa'da savaş rüzgarlarının estiği 1939 yılında, Fransa'nın Hatay'la ilgili tutumunun tamamen değiştiği görülmektedir. Nitekim, Fransa Başbakanı Daladier, Hatay sorunu ile ilgili yaptığı bir konuşmada, iki ülke arasında uzun süre çözülemeyen bu meselesinin en dostane şekilde çözüldüğünü, bu dostluk çabalarının devamını sağlamak amacıyla Fransız General Weygard'ın Türkiye'ye gönderildiğini ifade etmiştir $^{96}$. Daladier, bu demeciyle, Türkiye ile yeniden dostluk ilişkileri kurmak ve geliştirmek istediğini ortaya koymuştur.

Ulus ve Cumhuriyet gazetelerinde Hatay'ın anavatana katılmasıyla ilgili ilk haber, 14 Haziran 1939 tarihinde, Başbakan Refik Saydam'ın demecine dayandırılarak ve "Hatay Anavatana Kavuşuyor" başlı̆̆ıyla manşetten verilmiştir. Ulus gazetesinde yayınlanan haberin altında bir

\footnotetext{
94 Ulus, 15 Eylül 1938.

${ }^{95}$ Ulus, 9 Mayıs 1939.

${ }^{96}$ Ulus, 12 Mayıs 1939.
}

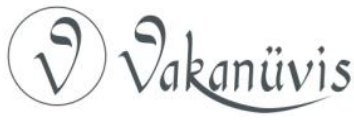


açıklama olmamasına rağmen küçük bir Hatay haritası mevcuttur ${ }^{97}$. Cumhuriyet gazetesinde yayınlanan haberde ise, Saydam'ın Cumhuriyet Halk Partisi meclis grubu toplantısında yaptığı konuşmaya yer verilmiştir. Dr. Refik Saydam konuşmasında, Hatay'ın anavatana katî olarak katılması için Fransa ile sürdürülen görüşmelerin tam bir anlaşma ile sonuçlandığının söylenebileceğini belirtmiş ve yakın bir gelecekte Hatay'ın anavatana katılacağını müjdelemiştir ${ }^{98}$. Yunus Nadi, Cumhuriyet Gazetesi'ndeki yazısında, Türkiye'nin Hatay meselesinde izlediği başarılı politikanın ilk uygulayııılarının hayatları ile sınırlı kalmamasını, bunun elden ele, nesilden nesle, şeften şefe aktarılarak sürdürülen bir politika haline getirilmesini temenni etmiştir ${ }^{99}$. 16 Haziran tarihinde Türkiye-Hatay sınırındaki sınır ve gümrük muameleleri kaldırılmıştır ${ }^{100}$.

Hatay'ın anavatana bağlanması konusunda Türk-Fransız görüşmeleri kesin sonucunu 23 Haziran'da verdi ve Paris'te Türkiye-Fransa Karşılıklı Yardım ve İşbirliği Antlaşması imzalandı ${ }^{101}$. Ankara'da da Hatay'ın anavatana katılmasını sağlayan ve güney sınırları tespit eden diğer bir antlaşma imzalandı. Aynı gün Hatay Meclisi de Türkiye ile birleşme kararı alarak kendini feshetti ${ }^{102}$. Cumhuriyet Gazetesi, 24 Temmuz tarihli manşetinde, Hatay'ın Türkiye Cumhuriyeti'ne ilhakını müjdelemiş ve Fransa ile varılan antlaşmanın Ankara'da büyük bir törenle imzalandığını belirtmiştir ${ }^{103}$. Hatay Antlaşması, 16 Haziran 1939 tarihinde Ulus gazetesinde yayınlanmıştır ${ }^{104}$. Fransa'nın bu antlaşmaları imzalamaya yanaşmasının en önemli sebeplerinden birinin de Hitler Almanya'sının Avrupa'da büyük bir tehdit haline gelmesi ve II. Dünya Savaşı'nın kaçınılmaz bir hal alması olduğu açıktır.

Hatay Meclisi dağılırken İstiklal Marşı eşliğinde Hatay Bayrağı gönderden indirilerek, yerine Türk bayrağı çekilmiştir. Meclis binasının

\footnotetext{
${ }^{97}$ Ulus, 14 Haziran 1939.

${ }^{98}$ Cumhuriyet, 14 Haziran 1939.

${ }^{99}$ Cumhuriyet, 16 Haziran 1939.

${ }^{100}$ Cumhuriyet, 16 Haziran 1939.

${ }^{101}$ Cumhuriyet, 23 Temmuz 1939.

102 Ulus, 24 Haziran 1939; Dayı, a.g.m., s. 339.

${ }^{103}$ Cumhuriyet, 24 Haziran 1939.

${ }^{104}$ Ulus, 16 Haziran 1939.
}

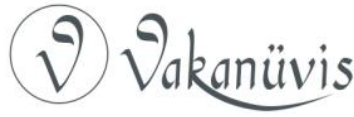


etrafında on binlerce kişilik kalabalık coşkulu tezahüratlar yapmışlardır $^{105}$. 23 Haziran'da imzalanan Türk-Fransız Antlaşması, 30 Haziran tarihinde, TBMM'de görüşülerek, mevcut 344 üyenin oybirliği ve alkışlar eşliğinde kabul edilmiştir ${ }^{106}$. Konu ile ilgili olarak 1 Temmuz'da Cumhuriyet gazetesinde yayınlanan yazıda, Meclisin Hatay Anlaşmasını oy birliğiyle onayladığını ve Hatay'ın kalkınması için 5 milyon Lira tahsisat ayrılarak, valiye salahiyet verileceği ifade edilmiştir $^{107}$.

Hatay'da ilk kurtuluş bayramı büyük şenliklerle kutlanmış ve kutlamalara Antalya mebusu Tayfur Sökmen'in de aralarında bulunduğu birçok milletvekili ve subay da katılmıştır. Ayrıca Cumhurbaşkanı İsmet İnönü'nün, Tayfur Sökmen'in Hatay'ın anavatana kavuşması nedeniyle gönderdiği minnet ve şükran duygularını içeren telgrafına cevaben yazdığı telgraf da yayınlanmıştır. İnönü, telgrafında şöyle söylemektedir:

\section{"Tayfur Sökmen, Antalya Saylavı, Antakya}

Aziz Hatay'ın anavatana kavuşmasının sevinci büyük ve derindir. Bu mesud neticeye ulaşmasında unutulmaz hizmet hisseleri olan sayın Hataylıarı ve sizi muhabbetle anar, hararetle tebrik ederim.

$$
\text { Ismet inönü" } 108
$$

Yunus Nadi, 1 Temmuz tarihli Cumhuriyet gazetesinde yayınlanan makalesinde, Hatay Meclisinin aldığı karar üzerine, Hataylıların Fransız ordusunun tamamen çekileceği 23 Temmuz tarihini beklemeden büyük bayram şenlikleri yapmaya başladıklarını, yirmi yıllık bir hasretin sona ermesinin verdiği hissiyat ile Hataylıların kalplerinden coşarak bütün vatanı kaplayan sevinci zapt etmenin imkânsız olduğunu ve Hataylıların en büyük bayramlarını kutladıklarını ifade etmiştir ${ }^{109}$.

Türkiye Cumhuriyeti Hükümeti, Hatay vilayet merkezinin Antakya'da kurulmasına karar vermiş, Hatay'da af ilan ederek, 2 Eylül 1938 tarihine

\footnotetext{
${ }^{105}$ Cumhuriyet, 30 Haziran 1939.

${ }^{106}$ Tekin, a.g.e., s. 163.

${ }^{107}$ Cumhuriyet, 1 Temmuz 1939.

108 Cumhuriyet, 28 Haziran 1939.

${ }^{109}$ Cumhuriyet, 1 Temmuz 1939.
}

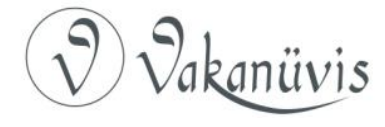


yani Hatay Meclisi'nin teşekkülüne kadar işlenen suçları affetmiştir ${ }^{110} .4$ Temmuz tarihli Cumhuriyet gazetesinde, Türk Ordusunun Hatay'a giriş tarihi olan 5 Temmuz'un yıldönümü için şenlikler düzenleneceği ve bu nedenle de hazırlıklar yapıldığı belirtilmiştir ${ }^{111} .6$ Temmuz tarihinde de Türk ordusunun Hatay’a girişinin yıldönümünün büyük bir coşkuyla kutlandığı ve halkın kutlamalara katılabilmek için geceden yollara düştüğü ifade edilmiştir ${ }^{112}$.

Hatay vilayetinin ilk valisi Şükrü Sökmen Süer, tayin emrini almak üzere, 9 Temmuz 1939 'da Ankara'ya hareket etmiştir. Süer, 23 Temmuz'da yapılacak olan büyük şenliklere, Türk hükümetinin en büyük mülkiye memuru sıfatıyla katılacaktı. Hatay ile Suriye arasındaki sınır taşı, 8 Temmuz'da kaldırıldı ve yerine Türkiye- Suriye sınır taşı konuldu ${ }^{113}$.

İtalya, Türk-Fransız Antlaşmasının San Remo Antlaşması'na aykırı olması gerekçesiyle, Hatay'ın ilhakını kabul etmediğini belirterek, 10 Temmuz tarihinde konuyla ilgili Fransa hükümetine bir nota vermişse de $^{114}$ İtalya'nın itirazları ve notaları bir sonuç vermemiş ve Fransa bu devlete verdiği cevapta, Hatay'ın Türkiye'ye ilhakının 1921 Ankara Antlaşması'nın kaçınılmaz bir sonucu olduğunu belirterek, Hatay'ın Türkiye'ye geri verilmesinin Türk-Suriye ilişkilerini iyileştireceğini bildirmiştir $^{115}$. Hatay'ın Türkiye'ye verilmesine tepki gösteren diğer bir devlet olan Suriye'de partiler ve meclis, Fransa ve Milletler Cemiyeti'ne telgraflar göndererek durumu protesto etmiş ${ }^{116}$, ancak bu protestolar da sonuçsuz kalmıştır.

23 Temmuz 1939 sabahı saat 07.00'da Hatay'da kalan son Fransız askeri birliği kışladan ayrılmıştır. Türk ve Fransız birliklerinin katıldığı törenle saat 07.45 'te Fransız bayrağı indirilmiş ve yerine İstiklal Marşı eşliğinde Türk bayrağı çekilmiştir. Böylece Atatürk'ün Türk milletine vermiş olduğu söz yerine gelmiş ve Hatay anavatana katî olarak

\footnotetext{
${ }^{110}$ Cumhuriyet, 2 Temmuz 1939.

${ }^{111}$ Cumhuriyet, 4 Temmuz 1939.

112 Cumhuriyet, 6 Temmuz 1939.

${ }^{113}$ Cumhuriyet, 10 Temmuz 1939.

${ }^{114}$ Cumhuriyet, 13 Temmuz 1939.

115 Pehlivanlı, a.g.e., s. 135-136.

116 Pehlivanlı, a.g.e., s. 136.
}

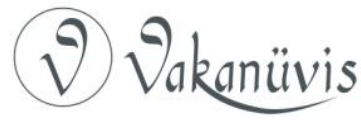


bağlanmıştır ${ }^{117}$. Suriye, 1944 yılında bağımsızlığını kazandıktan sonra, Şam'daki yabancı elçilere gönderdiği genelge ile uluslararası ve ikili anlaşmalara saygılı olacağını belirtmiş ve böylece dolaylı olarak Hatay'ın Türkiye'ye ilhakını tanımıştır. Türkiye de 1946 yılında Suriye'yi tanıyarak, Şam'da büyükelçilik açmıştır ${ }^{118}$.

\section{Sonuç}

Yeni Türkiye Cumhuriyeti'ni en çok uğraştıran sorunlardan biri olan Misak-ı Milli içerisinde yer alan Hatay'ın anavatana bağlanması meselesi, Mustafa Kemal Atatürk'ün ve Türk hükümetinin yoğun diplomasi trafiği ve izlenen politikalar sayesinde çözüme kavuşturulmuş ve Hatay, 1939 yılında anavatana kavuşmuştur. Atatürk'ün yoğun bir çaba sarf etmesine rağmen çözüldüğünü göremeden vefat ettiği Hatay Sorunu, ana kaynak olarak kullanılan Ulus ve Cumhuriyet gazetelerinde yoğun bir şekilde işlenmiştir.

Bu iki gazetede, özellikle dönemin büyük gazetecileri, F. Rıfkı Atay ve Yunus Nadi'nin yorumları ve makaleleri, süreci net bir şekilde ortaya koymuştur. Bu çerçevede, bir taraftan Türk hükümetinin girişimleri ortaya konulurken, diğer taraftan da Fransız ve Suriyelilerin Hatay'ı ellerinde tutmak için izlediği politikalar da ayrıntılı olarak ele alınmıştır. Dönemin bu iki önemli gazetesinde yer alan haberler sayesinde, Türk kamuoyu sorunun gelişimiyle ilgili bilgilenmiş ve aynı şekilde Türk halkının konuyla ilgili tepkileri de bu haberlerde yapılan yorumlara etki etmiştir.

\section{Kaynakça}

\section{Kitap ve Makaleler}

Ada, Serhan, Türk-Fransız ilişkilerinde Hatay Sorunu (1918-1939), İstanbul Bilgi Üniversitesi Yayınları, İstanbul, 2005.

Armaoğlu, Fahir, 20. Yüzyıl Siyasi Tarihi, Ankara, 1983.

Atabey, Figen, "Hatay'ın Anavatana Katılma Süreci", Avrasya Uluslararası Araştırmalar Dergisi, 4/7 (Temmuz 2015), s. 192-209.

\footnotetext{
117 Tekin, a.g.e., s. 228.

118 Pehlivanl, a.g.e., s. 136.
}

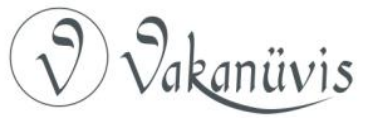


Atatürk'ün Söylev ve Demeçleri I-III, Derleyen: Nimet Arslan, Ankara, 1997.

Aydın, Ayşe, "Hatay Meselesinin Çözümü Esnasında Başbakan Celal Bayar'ın Faaliyetleri", Afyon Kocatepe Üniversitesi Sosyal Bilimler Dergisi, 14/1 (Haziran 2012), s. 143-153.

Dayı, S. Esin, "Hatay Devleti ve Hatay'ın Anavatana Katılması", Atatürk Üniversitesi Türkiyat Araştırmaları Enstitüsü Dergisi, 19 (2002), s. 331- 340.

Güneş, İhsan, Türk Parlamento Tarihi, c.1, Eskişehir, 2003.

Hatay'ın Kurtuluş Mücadelesinde Türk Ordusu, Yay. Haz: 39. Mekanize Piyade Tugay Komutanlığı Tarih Araştırma Grubu, ed. Mustafa Filiz, İskenderun, 2010.

Karakoç, Ercan, "Atatürk'ün Hatay Davası", Bilig, 50 (Yaz 2009), s. 97-118.

Melek, Abdurrahman, Hatay Nasıl Kurtuldu, Ankara, 1966.

Pehlivanlı, Hamit, Yusuf Sarınay, Hüsamettin Yıldırım, Türk Dış Politikasında Hatay, Ankara, 2001.

Sarınay, Yusuf, "Atatürk Dönemi Türk Dış Politikası ve Hatay", Anavatana Katılışının 60. Yıldönümünde Hatay, Ankara, 2001.

Saygı, Tarık, "Lozan Antlaşması'nda Musul Sorunu ve Hatay Meselesi", Yalova Sosyal Bilimler Dergisi, 5/10 (2015), s. 157-174.

Soysal, İsmail, "Türk-Fransız İlişkileri", Türkiye Diyanet Vakfı İslam Ansiklopedisi, c. 13, İstanbul, 1996, s. 181-184.

Sökmen, Tayfur, Hatay'ın Kurtuluşu Için Harcanan Çabalar, Ankara, 1978.

TBMM Zabıt Ceridesi, 6. Cilt (5. Dönem, 2. Yasama Yılı), 1 Kasım 1935, https://www.tbmm.gov.tr/tutanaklar/TUTANAK/TBMM/d05/ c006/tbmm05006001.pdf

Tekin, Mehmet, Hatay Tarihi, Osmanlı Dönemi, Ankara, 2000.

\section{Gazeteler}

Cumhuriyet, 13 Eylül 1936.

Cumhuriyet, 25 Kasım 1937.

Cumhuriyet, 24 Eylül 1936.

Cumhuriyet, 30 Kasım 1937.

Cumhuriyet, 12 Ekim 1936.

Cumhuriyet, 21 Aralık 1937.

Cumhuriyet, 2 Kasım 1936

Cumhuriyet, 28 Mayıs 1938.

Cumhuriyet, 16 Kasım 1936.

Cumhuriyet, 17 Haziran 1938.

Cumhuriyet, 17 Kasım 1936.

Cumhuriyet, 23 Haziran 1938.

Cumhuriyet, 3 Aralık 1936.

Cumhuriyet, 14 Haziran 1939.

Cumhuriyet, 5 Aralık 1936.

Cumhuriyet, 16 Haziran 1939.

Cumhuriyet, 10 Aralık 1936

Cumhuriyet, 24 Haziran 1939.

Cumhuriyet, 18 Aralık 1936

Cumhuriyet, 28 Haziran 1939.

Cumhuriyet, 7 Ocak 1937.

Cumhuriyet, 30 Haziran 1939.

Cumhuriyet, 12 Ocak 1937.

Cumhuriyet, 1 Temmuz 1939.

Cumhuriyet, 21 Ocak 1937.

Cumhuriyet, 2 Temmuz 1939.

Cumhuriyet, 29 Ocak 1937.

Cumhuriyet, 10 Temmuz 1939.

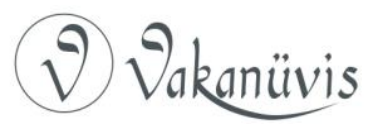


Cumhuriyet, 13 Temmuz 1939.

Cumhuriyet, 23 Temmuz 1939.

Cumhuriyet, 4 Temmuz 1939.

Cumhuriyet, 6 Temmuz 1939.

Ulus, 12 Eylül 1936.

Ulus, 23 Eylül 1936.

Ulus, 25 Eylül 1936.

Ulus, 29 Eylül 1936.

Ulus, 30 Eylül 1936.

Ulus, 12 Ekim 1936.

Ulus, 2 Kasım 1936.

Ulus, 7 Kasım 1936.

Ulus, 15 Kasım 1936.

Ulus, 16 Kasım 1936.

Ulus, 21 Kasım 1936.

Ulus, 25 Kasım 1936.

Ulus, 4 Aralık 1936.

Ulus, 5 Aralık 1936.

Ulus, 10 Aralık 1936.

Ulus, 18 Aralık 1936.

Ulus, 25 Aralık 1936.

Ulus, 5 Ocak 1937.

Ulus, 8 Ocak 1937.

Ulus, 13 Ocak 1937.

Ulus, 21 Ocak 1937.

Ulus, 28 Ocak 1937.

Ulus, 29 Ocak 1937.

Ulus, 27 Şubat 1937.

Ulus, 10 Mart, 1937.

Ulus, 3 Nisan 1937.

Ulus, 8 Mayıs 1938.
Ulus, 30 Mayıs 1937.

Ulus, 2 Haziran 1937.

Ulus, 16 Haziran 1937.

Ulus, 10 Kasım 1937.

Ulus, 14 Kasım 1937.

Ulus, 29 Kasım 1937.

Ulus, 30 Kasım 1937.

Ulus, 1 Aralık 1937.

Ulus, 16 Aralık 1937.

Ulus, 2 Mart 1938.

Ulus, 21 Mayıs 1938.

Ulus, 30 Mayıs 1938.

Ulus, 1 Haziran 1938.

Ulus, 16 Haziran 1938.

Ulus, 21 Haziran 1938.

Ulus, 22 Haziran 1938.

Ulus, 27 Haziran 1938.

Ulus, 3 Temmuz 1938.

Ulus, 5 Temmuz 1938.

Ulus, 7 Temmuz 1938.

Ulus, 3 Ağustos 1938.

Ulus, 5 Eylül 1938.

Ulus, 9 Eylül 1938.

Ulus, 15 Eylül 1938.

Ulus, 9 Mayıs 1939.

Ulus, 12 Mayıs 1939.

Ulus, 14 Haziran 1939.

Ulus, 16 Haziran 1939.

Ulus, 24 Haziran 1939.

Ulus, 7 Mart 1938. 